\title{
PROSEDUR PENGADAAN BARANG IMPOR PRODUK SEPATU DI PT SINAR PRATAMA AGUNG JAKARTA
}

\author{
Sugiyah $^{1,}$, Nurhidayati ${ }^{2}$ \\ Program Studi Administrasi Perkantoran; Universitas Bina Sarana Informatika ${ }^{1}$ \\ Jl.Margonda Raya Depok \\ Sugiyah.sgy@bsi.ac.id ${ }^{1}$, nurhidayati.nht@bsi.ac.id²
}

\begin{abstract}
Procurement of goods is important for the company, because it is very important to the company and corporate profits. Procurement can be done in several ways, one of which is by way of import. In this time, an activity of importing a goods is not a difficult way because and many offer services to import the goods. Methods of data collection is done by observation, interview and documentation. Steps for procurement of goods is start from product selection, ordering of goods, making and checking documents to import, delivery of goods, payment of invoices, PIB payments, processes on shipping and customs, further processing of ports arriving at destination, carrying out goods, and finally can check the condition of goods in the warehouse. Documents required for the procurement process of imported goods are: Purchase Order, Invoice, Packing List, Bill of Lading, Certificate of Origin, Insurance, and Surveyor Report. To facilitate the process on customs and shipping until the expenditure of goods from the port can use forwarder services. This makes it easier and very helpful in the procurement process by importing.
\end{abstract}

\section{Keywords: Procurement of Goods, Import}

\begin{abstract}
Abstrak - Pengadaan barang merupakan hal yang penting dalam suatu perusahaan dagang, karena sangat berpengaruh terhadap jalannya suatu perusahaan dan keuntungan perusahaan. Pengadaan barang dapat dilakukan dengan beberapa cara, salah satunya yaitu dengan cara impor. Pada saat ini kegiatan mengimpor barang bukanlah hal yang sulit dan banyak yang menawarkan jasa untuk mengimpor barang. Metode pengumpulan data dilakukan dengan cara observasi, wawancara dan dokumentasi. Prosedur pengadaan barang impor dilakukan mulai dari pemilihan produk barang, pemesanan barang, membuat dan pengecekan dokumen untuk mengimpor barang, pengiriman barang, pembayaran Invoice, pembayaran PIB, proses pada pelayaran dan beacukai, selanjutnya proses pengeluaran barang dari pelabuhan hingga barang tiba pada tempat tujuan, penerimiaan barang, dan terakhir kemudian dapat
\end{abstract}


melakukan pengecekan terhadap kondisi barang pada gudang. Dokumen yang dibutuhkan untuk proses pengadaan barang impor tersebut diantaranya yaitu Purchase Order, Invoice, Packing List, Bill of Lading, Certificate of Origin, Insurance, dan Laporan Surveyor. Untuk mempermudah dalam proses pada bea cukai dan pelayaran hingga pengeluaran barang dari pelabuhan dapat menggunakan jasa forwarder. Hal ini membuat semakin mudahnya dan sangat membantu dalam proses pengadaan barang dengan cara impor.

\section{Key Word : Pengadaan Barang, Impor}

\section{PENDAHULUAN}

Pertumbuhan bidang indutri dan perdagangan yang cepat berdampak pada persaingan bisnis yang semakin ketat. Satu sisi persaingan memberikan efek positif sebagai motivasi melakukan evaluasi terhadap apa yang sudah dikerjakan dan di sisi berdampak sebagai ancaman bagi perusahaan. Sebaliknya bagi konsumen semakin banyak persaingan maka semakin banyak pula pilihan untuk memilih produk yang sesuai dengan apa yang diharapkan merebut hati pelanggan.

Untuk itu perusahaan berlomba untuk merebut pelanggan dengan meningkatkan kepuasan kepada pelanggan, salah satu dengan memperhatikan produk perusahaan. Produk yang baik, harus dimulai dari pemilihan bahan baku, dan dilanjutkan dengan memperhatikan proses produksi dan inovasi sehingga menghasilkan produk yang berkualitas tinggi dan memenuhi kebutuhan dan selera konsumen.

Berkaitan dengan pengadaan barang, biasanya perusahaan membuat mekanisme/prosedur yang dijadikan pedoman. Sebagian perusahaan melakukan impor dalam pengadaan barang, karena berbagai alasan. Pengadaan barang dengan impor tentunya memerlukan dokumen-dokumen yang berbeda dibandingkan dengan pembelian barang lokal. Keperluan dokumen pendukung yang diperlukan untuk mengimpor barang saat ini sudah tersedia jasa forwarder (pengurusan impor) yang mengurus container di pelabuhan hingga container dapat keluar dan menuju ke perusahaan. Kondisi memudahkan perusahaan untuk mengimpor barang. Perusahaan akan membuat dokumen pendukung impor dan melakukan pembayaran, selanjutnya dalam pengurusan container di pelabuhan hingga keluarnya container dari pelabuhan menuju lokasi perusahaan dapat menggunakan jasa forwarder (pengurusan impor). 
Dengan keadaan yang mempermudah tersebut, membuat perusahaan lebih tertarik untuk melakukan impor barang.

Hartanto dan Utami dalam Widyastuti (2017) mengemukakan bahwa Pengendalian Persediaan bahan baku merupakan fungsi manajemen yang sangat penting karena persediaan merupakan investasi perusahaan yang besar nilai maupun fungsinya. Perusahaan perlu menerapkan perencanaan mengenai pengendalian persediaan yang memperkirakan ketepatan pengiriman dan ketepatan jumlah atau volume bahan baku.

Berdasarkan uraian yang dikemukakan di atas, maka penulis tertarik untuk melakukan penelitian dengan judul Analisa Prosedur Pengadaan Barang Impor Produk Sepatu di PT Sinar Pratama Agung Jakarta “ (Studi pada Divisi Purchasing PT Sinar Pratama Agung Jakarta).

\section{KAJIAN TEORI}

\subsection{Pengertian Pengadaan Barang}

Pengertian pengadaan barang/jasa menurut Sutedi dalam Rossita et al., (2014) mencakup penjelasan dari dari seluruh proses sejak awal perencanaan, persiapan, perijinan, penentuan pemenang lelang hingga tahap pelaksanaan dan proses administrasi pengadaan barang, pekerjaan atau jasa (jasa konsultasi teknis, jasa konsultasi keuangan, jasa konsultasi hukum atau jasa lainnya).

Margertha dalam Fiqran, dkk (2015) persediaan merupakan sejumlah bahan/barang yang disediakan oleh perusahaan baik berupa barang jadi, bahan mentah, maupun bahan dalam proses yang disediakan untuk menjaga kelancaran operasi perusahaan guna memenuhi kebutuhan konsumen setiap waktu".

\subsection{Faktor Pertimbangan Dalam Pemilihan Pemasok}

Dalam melakukan pengadaan barang, pemilihan pemasok barang diperlukan untuk mencapai tujuan perusahaan dengan berbagai pertimbangan. Terdapat beberapa faktor pertimbangan dalam pemilihan pemasok barang.

Siahaya (2013:40) mengemukan pendapanya terdapat beberapa faktor pertimbangan dalam melakukan pemilihan pemasok, yaitu :

1. Produk dan teknologi produksi

a. Mutu Produk.

b. Teknologi proses produksi.

2. Distribusi dan teknologi informasi 
a. Desain produk baru.

b. Keterlibatan pemasok dalam kegiatan suplai.

c. Membangun sistem informasi.

d. Perbandingan dengan perusahaan sukses.

3. $\operatorname{Cost}(\mathrm{TCO})$

Meliputi syarat pembayaran, diskon, biaya pemesanan, biaya pemeliharaan, dan biaya logistik.

4. Reliabilitas

a. Reliabilitas karakter perusahaan.

b. Reliabilitas lead time pengadaan.

c. Kegiatan reseach \& deveploment

5. Sistem dan waktu pengadaan

a. Proses pengadaan mudah, cepat, dan efektif serta taat kepada peraturan yang berlaku.

b. Lead time pengadaan singkat.

\subsection{Pengertian Impor}

Impor merupakan perpindahan barang atau jasa dari suatu negara ke negara lain yang bersifat legal, biasa dikenal dalam perdagangan internasional. Impor merupakan tindakan memasukkan barang atau jasa dari negara lain ke dalam negeri. Jual beli ini melibatkan campur tangan bea cukai pada negara pengirim maupun penerima. Impor merupakan bagian utama dan penting dalam sendi perdagangan internasional.

Purnamawati (2013:13) menjelaskan bahwa "Impor adalah membeli barangbarang dari luar negeri sesuai dengan ketentuan pemerintah yang dibayar dengan menggunakan valuta asing”.

Ismiyadi dan Indarniati (2017:16) menjelaskan bahwa barang impor adalah setiap barang yang dimasukan dari luar negeri yang melakukan impor. Importir adalah orang atau badan usaha yang melakukan kegiatan impor.

\subsection{Prosedur dan ketentuan Impor}

Feriyanto, 2015:73) berpendapat pelaksanaan transaksi ekspor impor memperhatikan hal-hal berikut ini :

1. Kontrak jual beli (sales contract)

2. Membuka dan penerusan $\mathrm{L} / \mathrm{C}$ 
3. Menelitian syarat-syarat $\mathrm{L} / \mathrm{C}$

4. Menyiapan dokumen pengapalan.

5. Memeriksa dokumen-dokumen - oleh bank yang menegosiasi wesel, bank pembuka dan importir.

6. Menyerahkan dokumen untuk pembayaran - oleh eksportir, bank yang menegosiasi wesel.

7. Menyelesaiakan pembayaran oleh bank yang menegosiasi wesel, bank pembuka dan importir.

Dalam kontrak jual beli antara eksportir dan importer. Peran bank sebagai menangani dan mengawasi dokumen L/C transaksi yang bersangkutan.

Bila akan melakukan kegiatan impor, setiap orang atau perusahaan berbadan hokum terlebih dahulu harus melengkapi diri dengan Surat Keterangan Domisili Usaha (SKDU), Nomor Pokok Wajib Pajak (NPWP), Surat Izin Usaha Perdagangan (SIUP), dan Tanda Daftar Perusahaan (TDP).

\subsection{Tahapan-Tahapan Dalam Ekspor Impor}

Tahapan dalam mengimpor barang menurut Feriyanto (2015:79) sebagai berikut :

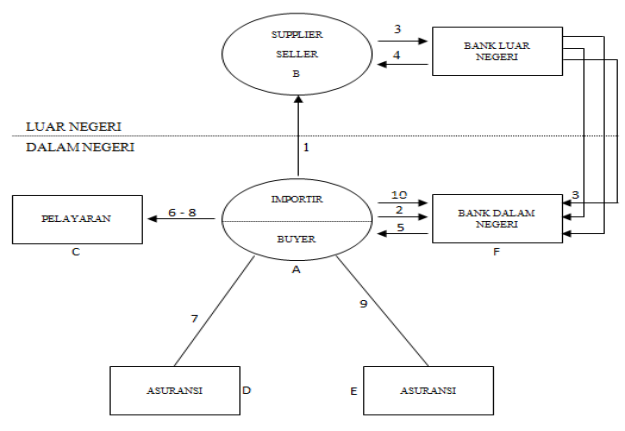

Sumber: Feriyanto (2015:79)

Gambar II.2. Tahapan-Tahapan Dalam Ekspor Impor

Keterangan:

1. Mencari importir (co-partner) di luar negeri, dapat dengan cara:

a. Mencari informasi di kantor kadin, kadinda, panjatapda (panitia kerja tetap daerah) di tingkat propinsi, dunia maya.

b. Referensi dari importir lain.

c. Kontak langsung. 
2. Membuat sales contract

a. Yaitu berbagai komitmen yang telah disepakati secara lisan yang dituangkan dalam bentuk tertulis.

b. Yang perlu diperhatikan dalam penyusunan sales contract diantaranya Harga jual barang, kondisi harga barang, jenis L/C yang akan diminta importir, pengapalan barang secara parsial atau keseluruhan, tanggal berlaku.

3. Transfering adalah eksportir melalui jasa angkutan darat atau pengusaha organda mengirim barang komoditas ekspor dari gudang milik eksportir ke gudang lini 1.

4. Loading yaitu kegiatan menumpuk barang di gudang lini 2. Setelah kapal sandar di dermaga dan siap menerima muatan, eksportir melalui jasa bongkar muat melanjutkan dengan menaikkan atau memuat barang ke dalam kapal.

5. Negotiating yaitu kegiatan eksportir dalam mempersiapkan semua dokumen ekspor sebagaimana diminta di dalam L/C secara lengkap, benar dan sempurna. Tujuannya agar tidak unpaid yaitu bank devisa di luar negeri tidak bersedia membayar atau menunda transfer valuta hasil ekspor ke negotiating bank.

\subsection{Dokumen Impor}

Dalam proses impor terdapat dokumen-dokumen yang dibutuhkan sebagai salah satu persyaratannya. Menurut Feriyanto (2015:97) dokumen impor terbagi menjadi 2, yaitu :

1. Dokumen Induk

Yang dimaksud dengan dokumen induk adalah dokumen inti yang dikeluarkan oleh Badan Pelaksanaan Utama Perdagangan Internasional, yang memiliki fungsi sebagai alat pembuktian pelaksanaan suatu transaksi. Termasuk dalam dokumen ini antara lain:

\section{a. Letter Of Credit $(L / C)$}

merupakan dokumen yang dikeluarkan bank atas permintaan importir yang ditunjukan kepada eksportir di luar negeri yang menjadi relasi importir tersebut, yang memberikan hak kepada eksportir untuk menarik wesel-wesel atas importir

b. Bill Of Lading $(B / L)$ 
Yaitu tanda terima barang yang telah dimuat di dalam kapal laut, sebagai bukti kepemilikan barang dan bukti adanya kontrak atau perjanjian pengangkutan barang melalui laut.

1) Fungsi $B / L$

a) Sebagai Bukti tanda penerimaan barang, yaitu barang-barang yang diterima pengangkut (Carrier) dari shipper (pengirim barang atau eksportir) ke tempat tujuan, selanjutnya diserahkan kepada pihak penerima (consignee atau importir).

b) Sebagai Bukti pemilikan atas barang (document of title), artinya orang yang memegang $\mathrm{B} / \mathrm{L}$ sebagai pemilik dari barang-barang yang tercantum pada $\mathrm{B} / \mathrm{L}$.

c) Sebagai Bukti perjanjian pengangkutan dan penyerahan barang antara pihak pengangkut dengan pengiriman.

2) Jenis-Jenis $B / L$

Berdasarkan pernyataan yang terdapat pada B/L dapat dibedakan:

a) Received for Shipment $B / L$

Artinya bahwa barang-barang telah diterima oleh perusahaan pelayaran untuk dikapalkan, tetapi belum benar-benar dimuat atau dikapalkan pada batas waktu yang ditetapkan dalam L/C yang bersangkutan.

b) Shipped on Board B/L

B/L dikeluarkan apabila persusahaan perkapalan yang bersangkutan mengetahui bahwa barang-barang yang akan dikirim benar-benar telah berada atau dimut di atas kapal.

c) Short Form B/L

Yaitu B/L berisi catatan singkat barang-barang yang dikapalkan (tidak termasuk syarat-syarat pengangkutan).

d) Long Form B/L

$\mathrm{B} / \mathrm{L}$ yang memuat syarat-syarat pengangkutan secara terperinci.

e) Through $B / L$

Dikeluarkan apabila terjadi transshipment akibat tidak tersedianya jasa langsung ke pelabuhan tujuan.

f) Combined Transport B/L

$\mathrm{B} / \mathrm{L}$ ini digunakan saat terjadi transshipment kemudian dilanjutkan dengan pengangkutan darat. 
g) Charter Party $B / L$

$\mathrm{B} / \mathrm{L}$ digunakan apabila pengangkutan dengan charter (sewa borongan sebagian/sebuah kapal).

h) Liner $B / L$

Adalah $\mathrm{B} / \mathrm{L}$ untuk pengangkutan barang dengan kapal yang telah memiliki jalur perjalanan serta persinggahan yang sudah terjadwal

c. Faktur (Invoice)

Adalah dokumen penting dalam perdagangan, data-data dalam invoice akan dapat diketahui berapa jumlah wesel yang akan dapat ditarik, jumlah penutupan asuransi, dan penyelesaian segala macam bea masuk.

\subsection{Pembayaran Transaksi Impor}

Menurut Feriyanto (2015:89) Proses pembayaran antar negara dapat dilakukan melalui berbagai cara antara lain :

1. Pembayaran Secara Tunai (Cash Payment) atau Pembayaran Dimuka (Advance Payment)

Dalam sistem pembayaran ini pembeli (Importir) membayar dimuka (pay in advance) kepada penjual (Eksportir) sebelum barang-barang dikirim oleh penjual tersebut.

Faktor pertimbangan dilakukannya sistem ini antara lain:

a. Kepercayaan Importir terhadap Eksportir

b. Keyakinan Importir bahwa negara Eksportir tidak akan melarang ekspor

c. Keyakinan Importir bahwa pemerintah Importir mengijinkan pembayaran dimuka.

d. Importir mempunyai likuiditas yang cukup.

Hal ini digunakan dalam kondisi pasar yang baik bagi penjual. Besarnya pembayaran biasanya $100 \%$ dari besarnya barang yang diekspor.

2. Pembayaran Kemudian (Open Account)

Sistem pembayaran dimana belum dilakukan pembayaran oleh importir kepada eksportir sebelum barang dikapalkan atau tiba dan diterima importir atau sebelum waktu tertentu yang telah disepakati. Eksportir setelah melakukan pengapalan barang akan mengirimkan invoice kepada importer, akan mencantumkan waktu tertentu kapan importir harus melakukan pembayaran. 
Sistem pembayaran ini dapat terjadi apabila :

a. Eksportir dan importir saling percaya

b. Barang-barang dan dokumen akan langsung dikirim kepada pembeli

c. Eksportir memiliki dana yang lebih

d. Tidak ada peraturan di negara importir yang melarang transfer pembayaran.

Selanjunya ada resiko yang dapat terjadi jika menggunakan sistem pembayaran ini antara lain :

a. Eksportir tidak mendapat jaminan apakah importir akan membayar.

b. Dalam hal importir tidak membayar, eksportir akan kesulitan dalam membuktikannya di pengadilan karena tidak ada bukti-bukti.

c. Penyelesaian perselisihan akan menimbulkan biaya bagi eksportir.

3. Wesel Inkaso (Collection Draft)

Dalam sistem ini eksportir memiliki hak pengawasan barang-barang sampai weselnya (draft) dibayar importir. Eksportir atau penarikan wesel (drawer) mengapalkan barang sementara dokumen pemilikan atas pengiriman barang secara langsung atau melalui bank importir dikirim ke importir.

4. Konsinyasi (Consignment)

Sistem pengiriman barang-barang ekspor pada importir di luar negeri dimana barangbarang tersebut dikirim oleh eksportir sebagai titipan untuk dijualkan oleh importir dengan harga yang telah ditetapkan oleh eksportir, barang-barang yang tidak terjual akan dikembalikan kepada eksportir.

Sistem ini eksportir mempunyai hak milik atas barang sedangkan importir hanya merupakan pihak yang dititipi barang untuk dijual. Resiko yang dapat timbul dalam sistem ini antara lain :

a. Modal terlalu lama tertimbun pada barang yang diperdagangkan.

b. Tidak ada kepastian eksportir akan menerima pembayaran.

c. Eksportir dapat menjadi korban kenakalan importir yang melaporkan barang yang terjual tidak sesuai dengan yang sebenarnya.

d. Bila importir tidak membayar, tidak ada bukti untuk menuntutnya di pengadilan.

5. Letter of Credit $(L / C)$ 
Suatu surat yang dikeluarkan oleh suatu bank atas permintaan importir yang ditunjukan kepada eksportir di luar negeri yang menjadi relasi importir tersebut, yang memberikan hak kepada eksportir itu untuk menarik wesel-wesel atas importir bersangkutan.

\subsection{Penerimaan Importir}

Penerimaan barang oleh importir sangatlah penting, karena importir menerima secara fisik barang yang berasal dari pabrikan, prinsipal, ataupun distributor sesuai dokumen pemesanan serta pengiriman, dengan kondisi sesuai persyaratan penanganan barang.

Menurut Ismiyadi dan Indarniati (2017:90) Kegiatan penerimaan barang importir ini terdiri dari tiga hal:

1. Bentuk fisik barang yang diterimakan Merupakan bentuk fisik barang yang dapat dirasakan, diraba oleh indera, serta dilihat secara kasat mata. Penerimaan bukan fisik akan menyebabkan beda proses serta hasil yang dicapai. Umumnya negatif, ketika menangani penerimaan barang tidak fisik, perlu adanya proses tambahan guna memastikan absahnya proses tersebut. Pada prinsipnya menerima barang ada beberapa hal:

a. Merupakan terima barang secara fisik dan langsung, bukan sekedar dokumen

b. Barang fisiknya jelas, dapat dilihat, dapat dibaca, dapat dirasakan, dapat dibandingkan dengan dokumen pengantar yang datang bersama barang

c. Pengecekan secara acak dan keseluruhan atas kondisi kemasan.

d. Kebenaran akan tanggal kadaluarsa serta tumpukan nomor barang.

e. Kesesuaian kuantitas barang dokumen

2. Dokumentasi

Dokumen pemesanan di mana barang yang diterima berdasarkan dokumen banyaknya barang yang diterima, jenis barang, serta kepastian bahwa barang yang diterima sama dengan barang yang dipesan. Dokumen itu sendiri merupakan pendamping nyata dari barang, yang bisa dibaca, dicocokan dengan keadaan barang yang dikirimkan.

3. Cara bagaimana menangani barang

Ini penting untuk diperhatikan, yaitu syarat menangani jual beli impor, khususnya kondisi barang harus dipersiapkan sangat baik. Apakah memerlukan penanganan Jurnal Akuntansi dan Manajemen Vol. 16 No. 02, Oktober 2019 
khusus karena faktor ukuran, berat, tingkat kesulitan dalam pengiriman, serta permasalahan lain. Para penjual harus mampu menangani barang jual beli sesuai siklus hidupnya, seperti suhu, waktu kadaluarsa, maksimalkan tumpukan. Sebaiknya menggunakan peralatan yang sesuai, seperti palet, drum, forklit. Juga harus paham tingkat keselamatan barang tersebut, terutama untuk bahan kimia, bahan yang mengandung racun, barang yang mudah meledak, dan sebagainya.

\section{METODELOGI PENELITIAN}

Penelitian ini dilaksanakan melalui tahapan yang dilakukan secara sistematik dan terukur agar nilai keilmiahan hasil penelitian yang dapat dipertanggungjawabkan. Adapun Jenis penelitian ini merupakan penelitian kualitatif deskriptif yang memiliki kajian keilmiahan, prinsip-prinsip, serta asumsi-asumsi fundamental ilmu pengetahuan, memanfaatkan penalaran deduktif yang didukung informasi yang valid, selanjutnya diolah dan dianalisa berdasarkan teori yang ada.

Sugiyono (2015) menjelaskan metode penelitian kualitatif adalah penelitian yang digunakan untuk menyelidiki, menemukan, menggambarkan, dan menjelaskan kualitas atau keistimewaan dari pengaruh sosial yang tidak dapat dijelaskan, diukur atau digambarkan melalui pendekatan kuantitatif.

Sedangkan Sugiarto (2015) Penelitian kualitatif adalah jenis penelitian yang temuan-temuannya tidak diperoleh melalui prosedur atau bentuk hitungan lainnya dan bertujuan mengungkapkan gejala secara holistic-kontekstual melalui pengumpulan data dari latar alami dengan memanfaatkan diri peneliti. Penelitian ini bersifat deskriptif dan menggunakan analisis dengan pendekatan induktif

Data diperoleh tidak dilakukan manipulasi atau perubahan pada variabel bebas, akan tetapi menunjukkan gambaran tentang suatu keadaan dimana nyata dan terjadi di lapangan.

Hal lain yang menentukan pemilihan suatu metode menurut Raco (2015) adalah data yang hendak diambil. Metode kualitatif menggunakan data yang diambil melalui wawancara, lapangan atau dokumentasi yang ada.

\section{HASIL DAN PEMBAHASAN}

\subsection{Prosedur pengadaan barang impor di PT Sinar Pratama Agung}

Berikut merupakan prosedur pengadaan barang impor produk sepatu di PT Sinar Pratama Agung Jakarta : 


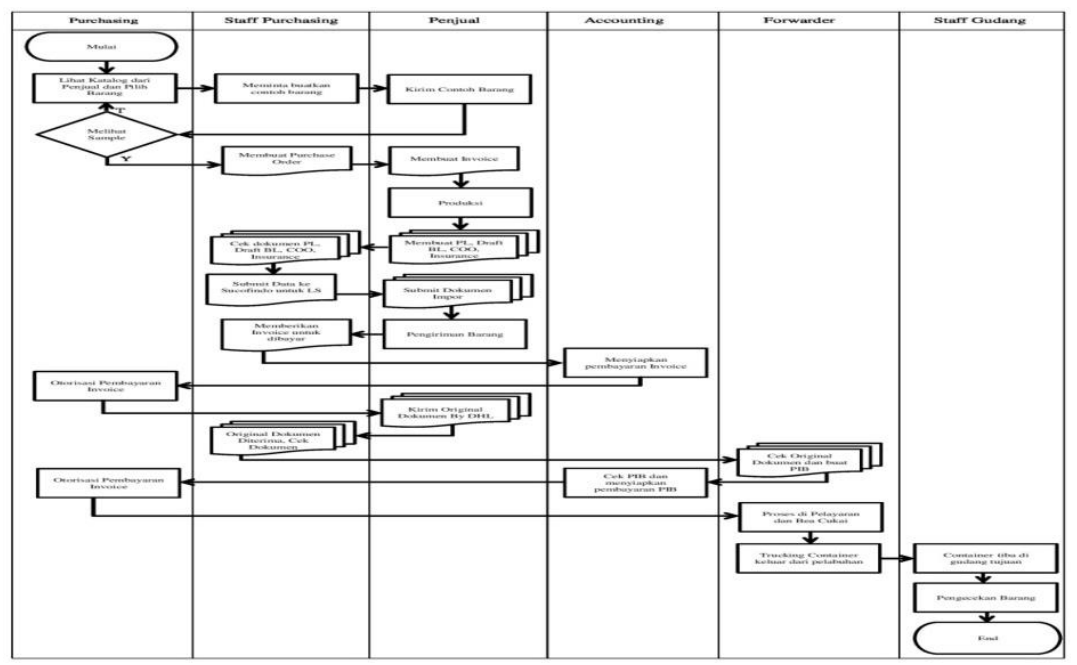

Sumber : Staff Purchasing PT Sinar Pratama Agung Jakarta (2018)

Gambar III.2. Flowchart Pengadaan Barang Impor PT Sinar Pratama Agung

Berdasarkan bagan di atas, prosedur pengadaan barang impor produk sepatu dapat dijelaskan sebagai berikut:

1. Purchasing melihat katalog sepatu dari berbagai supplier terlebih dahulu dan memilih produk yang sesuai kemudian menghubungi pihak supplier untuk meminta dibuatkan dan dikirimkan contoh barang tersebut.

2. Apabila sesuai dengan keinginan, maka pembeli akan membuat surat Purchase Order (PO) lalu dikirimkan ke pihak supplier melalui e-mail. Jika supplier menyanggupi pesanan, supplier akan membuatkan Invoice sebagai bentuk konfirmasi terhadap pesanan dari pembeli dan sebagai tagihan dengan jumlah yang harus dibayarkan oleh pihak pembeli yang dikirimkan melalui e-mail.

3. Supplier akan memulai memproduksi barang pesanan kurang lebih dengan waktu 40 hari tergantung banyaknya pesanan. Apabila barang hampir selesai sudah mencapai tahap finishing, supplier akan menginformasikan kepada pembeli dan mengirimkan contoh hasil produksi melalui foto.

4. Supplier membuat draft dokumen-dokumen impor seperti Packing List, Bill of Lading, Certificate of Origin, Insurance kemudian dikirimkan kepada pembeli melalui e-mail untuk diperiksa kembali agar pada seluruh dokumen sesuai dan tidak ada kesalahan dalam pengetikan. Supplier akan memesan kapal dan container untuk tujuan langsung ke Indonesia tepatnya Pelabuhan Tanjung Priok. 
5. Kemudian pembeli akan memproses data kedalam program Sucofindo Indonesia agar mendapatkan jadwal pengecekan barang oleh Sucofindo dan untuk mendapatkan Laporan Surveyor (LS). Setelah itu pihak Sucofindo China akan melakukan pengecekan terhadap barang yang akan dikirim apakah sudah sesuai dengan dokumen yang diajukan, apabila sudah sesuai antara barang dan dokumen yang diajukan maka Sucofindo akan menerbitkan dokumen yang disebut Laporan Surveyor (LS). Jika seluruh dokumen sudah sesuai, dokumen seperti Certificate of Origin, Insurance dan Bill of Lading akan di Issue ke pihak-pihak yang bersangkutan.

6. Barang yang sudah diperiksa oleh Sucofindo dapat dimasukan kedalam container dan dapat dinaikan ke atas kapal sesuai dengan tanggal kapal yang sudah dipesan. Kapal akan berangkat dari Pelabuhan di China menuju Pelabuhan Tanjung Priok. Ketika kapal sudah berangkat, pembeli akan melakukan pembayaran Invoice melalui Bank dengan melakukan Transfer Valuta Asing ke Rekening Bank supplier yang tertera pada Invoice lalu pembeli mengirimkan bukti pembayaran kepada supplier melalui e-mail. Kemudian Supplier mengirimkan Original Dokumen melalui DHL kepada pembeli.

7. Apabila kapal telah tiba di Pelabuhan Tanjung Priok, dan Original Dokumen sudah diterima oleh pembeli maka pembeli akan menginformasikan kepada forwarder untuk dibuatkan Pemberitahuan Impor Barang (PIB). Kemudian Original Dokumen tersebut diberikan kepada forwarder untuk di periksa kembali dan disesuaikan pada isi PIB. Jika sudah sesuai, pembeli akan membayarkan Bea Masuk, PPN dan PPH yang tertera pada PIB melalui Bank dengan menggunakan Giro. Setelah pembayaran, forwarder yang akan mengurus container di pelayaran dan Bea Cukai hingga container dapat dikirim dari pelabuhan menuju gudang pembeli.

8. Container yang sudah tiba di gudang pembeli, maka staff gudang akan menurunkan barang dari container kemudian akan memeriksa keadaan barang yang diterima sesuai Packing List apakah ada kekurangan barang atau terdapat barang yang rusak.

Berikut ini data tentang jumlah barang yang sudah di impor oleh PT Sinar Pratama Agung Jakarta 
Tabel 4.1 Jumlah Impor Barang Bulan Januari - Maret

\begin{tabular}{|l|r|r|r|r|}
\hline Brand & \multicolumn{1}{|l|}{ Januari } & \multicolumn{1}{|c|}{ Februari } & \multicolumn{1}{l|}{ Maret } & Jumlah Qty \\
\hline Sanrio & & 29.676 & 9.768 & 39.444 \\
\hline Connexion & 20.320 & 16.500 & & 36.820 \\
\hline Transformers & & 29.700 & 5.820 & 35.520 \\
\hline Disney & & 24.960 & 4.800 & 29.760 \\
\hline Nevada & & 28.198 & 900 & 29.098 \\
\hline Shimmer and Shine & & 13.380 & 7.908 & 21.288 \\
\hline Blaze & & 13.260 & 3.588 & 16.848 \\
\hline TOTAL Qty & 20.320 & 155.674 & 32.784 & 208.778 \\
\hline
\end{tabular}

Sumber : Staff Purchasing PT Sinar Pratama Agung Jakarta (2018)

Berdasarkan tabel diatas dapat disimpulkan bahwa selama dalam waktu 3 bulan PT Sinar Pratama Agung mengimpor barang berupa produk sepatu sebanyak 208.778 pasang. Brand paling banyak di impor yaitu Sanrio 39.444 pasang, kemudian Connexion 36.820 pasang, lalu Transformers 35.520 pasang.

Kegiatan mengimpor barang paling banyak terjadi pada bulan Februari mencapai 155.674 pasang, dikarenakan mendekati Lebaran dan barang-barang tersebut sudah harus dikirimkan ke berbagai toko di seluruh Indonesia di bulan April. Oleh karena itu kegiatan mengimpor barang di maksimalkan di bulan Februari.

\subsection{Dokumen dalam pengadaan barang impor pada PT Sinar Pratama Agung}

Berikut merupakan dokumen-dokumen yang digunakan dalam mengimpor barang oleh PT Sinar Pratama Agung :

1. Purchase Order (PO)

Purchase Order (PO) merupakan dokumen yang pertama kali dibutuhkan untuk memesan barang kepada pihak penjual.

2. Invoice

Invoice dikeluarkan oleh pihak penjual sebagai bentuk konfirmasi kesanggupan atas pesanan atau balasan dari Purchase $\operatorname{Order}(P O)$ yang telah dikirimkan sebelumnya. Berikut contoh Invoice pada PT Sinar Pratama Agung Jakarta : 


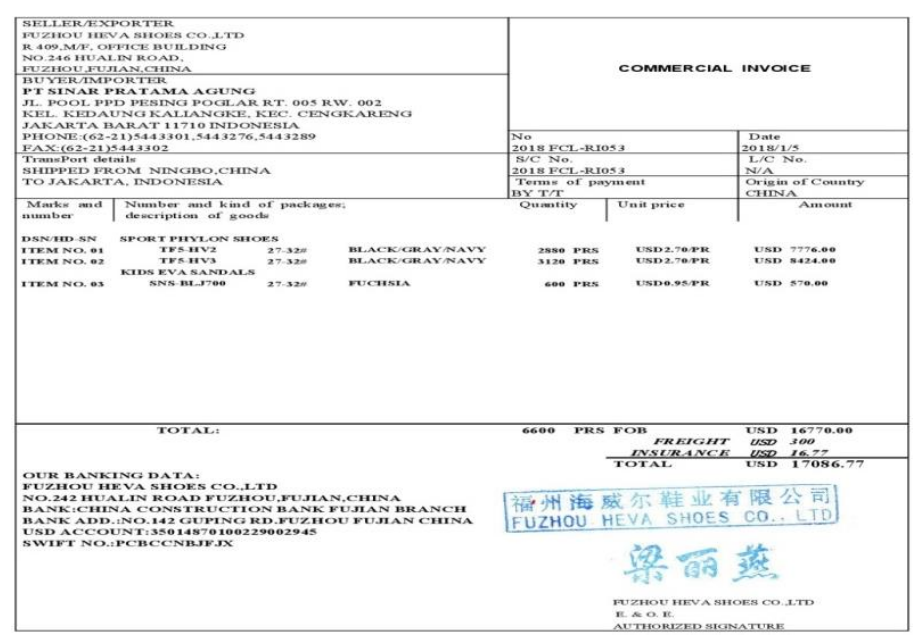

Sumber : Staff Purchasing PT Sinar Pratama Agung Jakarta (2018)

Gambar III.4. Invoice PT Sinar Pratama Agung

3. Packing List Packing List dikeluarkan oleh pihak penjual untuk mempermudah dalam pengecekan barang.

4. Bill of Lading $(B L)$

Bill of Lading $(B L)$ dikeluarkan oleh pihak pelayaran sebagai bukti telah dimuatnya barang di dalam kapal laut dan bukti kepemilikan barang. Berikut contoh Bill of Lading (BL) pada PT Sinar Pratama Agung Jakarta :

Pada Bill of Lading ( $B L)$ terdapat keterangan nama pengirim barang, pembeli, nama kapal yang memuat barang, pelabuhan muat barang, pelabuhan tujuan barang, nomor container, jenis barang, jumlah barang, jumlah karton, dan tanggal berangkat kapal.

5. Laporan Surveyor (LS)

Laporan Surveyor (LS) dikeluarkan oleh badan independent KSO SucofindoSurveyor Indonesia sebagai bukti telah dilakukannya inspeksi atau pengecekan terhadap barang yang dikirim oleh penjual kepada pembeli dan sudah dipastikan barang tersebut sudah sesuai dengan dokumen seperti PO, Invoice, dan Packing List yang diberikan. Berikut contoh Laporan Surveyor (LS) pada PT Sinar Pratama Agung Jakarta : 


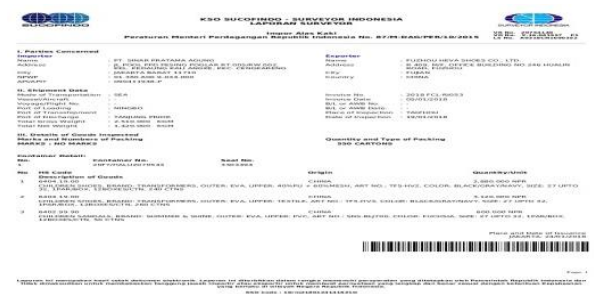

Sumber : Staff Purchasing PT Sinar Pratama Agung Jakarta (2018)

Gambar III.7. Laporan Surveyor (LS) PT Sinar Pratama Agung

Pada Laporan Surveyor (LS) terdapat nama pengirim barang, pembeli, nomor dan tanggal Invoice, berat bersih, dan berat kotor, pelabuhan muat, pelabuhan tujuan, tempat inspeksi, jumlah karton, kode HS, keterangan barang seperti bahan, merek, artikel barang, ukuran, jumlah barang dan jumlah karton.

6. Surat Keterangan Asal (Certificate Of Origin)

Surat Keterangan Asal (Certificate Of Origin) biasa disebut dengan COO/Form merupakan surat pernyataan untuk membuktikan asal dari suatu barang, digunakan untuk memperoleh fasilitas bea masuk dan sebagai bahan perhitungan jumlah bea masuk yang dibebankan kepada pembeli berdasarkan jenis barang.

Pada Laporan Surat Keterangan Asal (Certificate Of Origin) terdapat terdapat keterangan nama pengirim barang, pembeli, nama kapal yang memuat barang, tanggal keberangkatan kapal, pelabuhan tujuan barang, nomor dan tanggal Invoice, keterangan barang seperti kode HS, artikel barang, warna barang, jumlah karton, jumlah barang, jumlah harga barang, berat bersih barang, berat kotor barang, persentasi kriteria keaslian barang, total harga barang, total jumlah barang, total jumlah karton, dan lain-lain.

Berikut contoh Surat Keterangan Asal (Certificate Of Origin) pada PT Sinar Pratama Agung Jakarta :

7. Dokumen (Polis) Asuransi

Dokumen (Polis) Asuransi dikeluarkan oleh perusahaan asuransi atas permintaan penjual atau pembeli untuk menjamin keselamatan atas barang yang dikirim. Berikut contoh Dokumen (Polis) Asuransi pada PT Sinar Pratama Agung Jakarta

Pada Dokumen (Polis) Asuransi terdapat nama penerima asuransi atau nama pemilik barang, alamat penerima asuransi, nomor Bill of Lading, nama kapal pengangkut barang, nama pelabuhan asal, nama pelabuhan tujuan, keterangan 
jenis barang, jumlah karton barang dan jumlah asuransi barang biasanya jumlah asuransi barang yaitu $110 \%$ dari jumlah harga barang yang tertera pada Invoice.

\subsection{Kendala dalam pengadaan barang impor pada PT Sinar Pratama Agung dan cara menghadapinya}

1. Kesalahan dalam produksi misalnya barang dengan bahan sesuai sampel awal yang dipesan sudah habis jadi digantikan dengan bahan lain, kesalahan printing gambar tidak sesuai dengan gambar yang sudah disepakati awal, atau warna benang tidak sesuai. Solusinya dengan meminta potongan harga. Hal ini sesuai dengan pendapat pendapat Finoza (2012) yang menjelaskan salah satu tuntutan bahwa terjadinya penuntutan dapat disebabkan jenis barang yang dikirim tidak sesuai pesanan dengan minta potongan harga khusus (rafaksi) karena kesalahan mutu atau banyaknya barang yang rusak.

2. Kesalahan dalam produksi seperti tali sandal bengkok atau terdapat noda yang tidak dapat hilang, dan baru diketahui ketika barang sudah tiba ditujuan dan ditemukan saat pengecekan di gudang solusinya dengan meminta penggantian kepada pihak penjual karena terdapat barang yang tidak bagus sehingga mengakibatkan barang sulit dijual. Finoza (2012/ berpendapat barang yang dikirim mengalami kerusakan maka dapat mengajukan klaim minta dikirim barang baru sebagai pengganti barang yang rusak atau hilang dan biaya angkut ditanggung oleh penjual

3. Kendala dalam proses pengajuan inspeksi, terkadang lamanya proses data dari pihak sucofindo Indonesia ke sucofindo China sedangkan kapal sudah dipesan dalam waktu dekat. Solusinya dengan kedua pihak antara penjual dan pembeli saling menelpon pihak sucofindo di negara masing-masing untuk diinformasikan mengenai lambatnya proses data tersebut agar dapat dibantu segera mungkin untuk diberikan jadwal inspeksi. Barang harus dikirim dan diangkut dari suatu negara kenegara lainnya melalui bermacam peraturan seperti pabean, yang bersumber dari pembatasan yang dikeluarkan oleh masing-masing pemerintah (Kemendag, 2017)

4. Kendala dalam isi dokumen untuk impor misalnya terjadi kesalahan pengetikan yang mengakibatnya tidak sesuainya atau tidak selaras dengan dokumen impor lainnya. Solusi untuk menghadapi kendala tersebut yaitu dengan selalu melakukan cek ulang dokumen agar mengurangi terjadinya kesalahan dalam pembuatan dokumen impor. Feriyanto, (2015:73) berpendapat pelaksanaan transaksi ekspor 
impor memperhatikan pemeriksa dokumen-dokumen - oleh bank yang menegosiasi wesel, bank pembuka dan importir

\section{PENUTUP}

Berdasarkan pembahasan hasil penelitian di atas, maka dapat dirumuskan kesimpulan sebagai berikut:

1. Proses pengadaan barang impor di PT Sinar Pratama Agung, prosedurnya sudah jelas namun harus memiliki ketelitian yang lebih dikarenakan jika kurang teliti akan membuat menghambat dalam proses pengeluaran barang. PT Sinar Pratama Agung juga menggunakan jasa forwarder untuk mengurus pengeluaran barang di pelabuhan, hal ini sangat membantu pengerjaan dalam proses mengimpor barang. Jadi tidak diperlukan orang lapangan untuk mengurus keluarnya barang di pelabuhan, sudah menggunakan jasa ahlinya dalam bidang tersebut.

2. Dokumen yang digunakan dalam mengimpor barang pada dasarnya sama dengan yang biasanya digunakan untuk mengimpor barang pada umumnya. Dokumen tersebut yaitu dokumen induk dan dokumen penunjang yang terdiri dari Purchase Order, Invoice, Packing List, Bill of Lading, Certificate of Origin, Insurance, dan Laporan Surveyor. Dokumen tersebut merupakan suatu keharusan yang dibutuhkan dalam mengimpor barang, dan isi pada dokumen tersebut selalu dipastikan kesesuaiannya dengan keadaan barang yang diimpor.

3. Kendala yang dihadapi dalam pengadaan barang impor bermacam-macam, bisa dari faktor produksi, faktor program yang digunakan, maupun faktor ketelitiaan. Meskipun terdapat berbagai kendala namun tetap dapat terselesaikan dengan baik dan dapat dijadikan sebagai acuan untuk kedepannya. Kendala yang dihadapi pun tidak begitu fatal karena sudah ada ketentuan dan prosedurnya.

\subsection{Saran}

Saran yang diusulkan sebagai pengembangan terhadap prosedur pengadaan barang impor pada PT Sinar Pratama Agung yaitu :

1. Dalam pengadaan barang impor pasti memiliki berbagai kendala yang akan dihadapi, dengan jarak yang jauh hal ini sangat hanya mengandalkan atas dasar kepercayaan kepada masing-masing pihak. Dengan demikian sebaiknya kedua pihak harus saling memberikan yang terbaik misalnya dalam hasil produksi yang 
baik sesuai dengan yang pembeli harapkan, atau tepat janji dalam melakukan pembayaran berdasarkan kesepakatan-kesepakatan yang dibuat.

2. Sebelum melakukan pesanan barang sebaiknya memastikan terlebih dahulu apakah bahan baku untuk membuat barang tersebut masih tersedia, untuk menghindari berbedanya hasil produksi dengan contoh barang yang dipesan

\section{DAFTAR PUSTAKA}

Fiqran, M., Lubis, B. O., \& Prasetyo, A. 2015. Isbn : 978-602-72850-6-4 Isbn : 978602-72850-6-4. Sniptek, 177-186. Retrieved from

\section{http://konferensi.nusamandiri.ac.id/prosiding/index.php/sniptek/article/view/329/295}

Feriyanto, Andri. 2015. Perdagangan Internasional "Kupas Tuntas Presedur Ekspor Impor”. Kebumen: Mediatera

Finoiza, Lammuddin.2012.. Aneka surat sekretaris dan bisnis Indonesia. Jakarta. Diksi Insan Mulia

Ismiyadi dan Indarniati. 2017. Import Top Secret - Cara Impor Resmi Tanpa Ribet. Yogyakarta: Andi

Purnamawati, Astuti. 2013. Dasar-Dasar Ekspor Impor. Yogyakarta: UPP STIM YKPN.

Raco. JR, ME.M.Sc. Metode Penelitian Kualitatif, Grasindo, 2010

Rossita, A., Nurchana, A., Haryono, B. S., Adiono, R., Publik, J. A., Administrasi, F. I., \& Brawijaya, U. 2014. Efektivitas E-Procurement Dalam Pengadaan Barang / Jasa ( Studi terhadap Penerapan E-Procurement dalam Pengadaan Barang / Jasa di Kabupaten Bojonegoro ). Jurnal Administrasi Publik, 2(2), 355-359. Retrieved from

https://media.neliti.com/media/publications/77897-ID-efektivitas-e-procurement-dalampengadaa.pdf

Siahaya, Willem. 2013. Sukses Supply Chain Management. Jakarta: In Media.

Sugiarto, Eko. 2015 Proposal penelitian kualitatif: skripsi dan Tesis, Suaka Media,Yogyakarta

Widyastuti, I., \& Hamdi, A. 2017. Sistem Informasi Impor Bahan Baku Berbasis Web Sebagai Upaya Minimalisasi Biaya Persediaan. Jurnal Komputer Dan Informasi, 2(2), 55-64. Retrieved from

http://ejournal.bsi.ac.id/ejurnal/index.php/ijcit/article/view/2952/1886 
http://bppp.kemendag.go.id/media_content/2017/08/Analisis

Kebijakan_Impor_Produk_Tertentu.pdfLaporan 